1984

\title{
Individuals as Subjects of International Law
}

Mark Weston Janis

University of Connecticut School of Law

Follow this and additional works at: https://opencommons.uconn.edu/law_papers

Part of the International Law Commons

\section{Recommended Citation}

Janis, Mark Weston, "Individuals as Subjects of International Law" (1984). Faculty Articles and Papers. 408.

https://opencommons.uconn.edu/law_papers/408 


\section{HEINONLINE}

Citation:

M. W. Janis, Individuals as Subjects of International Law, 17 Cornell Int'l L.J. 61 (1984)

Content downloaded/printed from $\underline{\text { HeinOnline }}$

Mon May 13 10:19:38 2019

-- Your use of this HeinOnline PDF indicates your acceptance of HeinOnline's Terms and Conditions of the license agreement available at https://heinonline.org/HOL/License

-- The search text of this PDF is generated from uncorrected OCR text.

-- To obtain permission to use this article beyond the scope of your HeinOnline license, please use:

\section{Copyright Information}

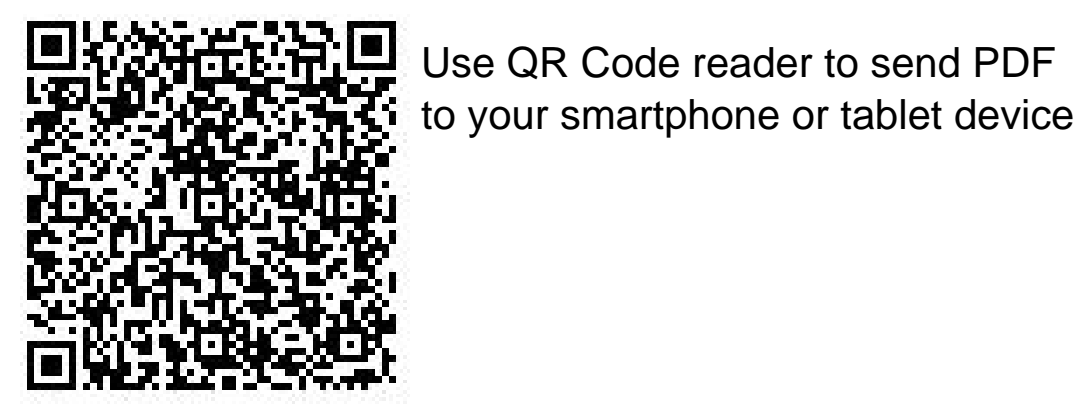




\title{
INDIVIDUALS AS SUBJECTS OF INTERNATIONAL LAW
}

\author{
M.W. Janis†
}

Legal positivism has long provided the usual theory for comprehending international law. The typical positivist definition of international law is grounded on a subject-based differentiation between international and municipal rules. Positivism views international law as a set of rules with states as its subjects. Municipal law is thought of as pertaining to individuals who are subjects of a single state. This Article rejects the positivist subjectbased approach to international law and calls for a definition of the discipline that recognizes individuals as subjects of international law.

This Article is divided into three parts. First, it briefly reviews the development of the positivist theory of international law. Second, it tests the subject-based approach against some realities of international practice and shows that international law actually has long involved individual rights and obligations. Finally, it suggests that a different, albeit older, theoretical foundation for international law may be a better way to encompass individuals as subjects of international law.

\section{POSITIVISM AND THE DEVELOPMENT OF THE SUBJECT- BASED DEFINITION OF INTERNATIONAL LAW}

Before positivism, there was no theoretical insistence that the rules of the law of nations applied only to states. William Blackstone reflected the sentiment of the middle eighteenth century. ${ }^{1}$ For Blackstone, individuals and states were both proper subjects of the law of nations. He drew no dividing line between what later came to

$\dagger$ Professor of Law, University of Connecticut School of Law.

1. The law of nations is a system of rules, deducible by natural reason, and established by universal consent among the civilized inhabitants of the world; in order to decide all disputes, to regulate all ceremonies and civilities, and to insure the observance of justice and good faith, in that intercourse which must frequently occur between two or more independent states, and the individuals belonging to each.

4 W. BLACKSTONE, CoMmentaries on the LAwS OF England 66 (facsimile of 1st ed. 1765-1769, University of Chicago, ed. 1979). 
be called public and private international law. ${ }^{2}$ Blackstone distinguished his law of nations from other sorts of law not on the basis of its subjects but because of its sources. He saw the rules of the law of nations as universal, emanating either from natural justice or from the practice of many states. ${ }^{3}$ Municipal legal rules, however, emanated from a single state.

In 1789, Jeremy Bentham created the term "international law" in his Introduction to the Principles of Morals and Legislation ${ }^{4}$ Bentham defined the new concept as the law which relates to "the mutual transactions between sovereigns as such."s He thought that "as to any transactions which may take place between individuals who are subjects of different states, these are regulated by the internal laws, and decided upon by the internal tribunals" of individual sovereign states. ${ }^{6}$ Categorizing laws on the basis of "the persons whose conduct is the object of the law," Bentham concluded that international law had only states as its subjects. ${ }^{7}$ While categorizing rules on the basis of the subjects to be governed is logical enough, it plainly was wrong for Bentham to assume that international law so defined was equivalent to the traditional law of nations. ${ }^{8}$ There were significant differences between the two. ${ }^{9}$

Two early nineteenth century positivists promoted the notion that the individual was not a proper subject of international law. Joseph Story, complaining that no treatise existed on the subject, crafted "private" international law to parallel Bentham's "public" international law. ${ }^{10}$ Public international law went to international matters affecting states, while private international law concerned

2. Blackstone's law of nations included "mercantile questions, such as bills of exchange and the like," "all marine cases" and "disputes relating to prizes, to shipwrecks, to hostages, and ransom bills." Id. at 67.

3. Id. at 66-67.

4. J. Bentham, An INTRoduction to the Principles of Morals and LegislaTION 6 (J. Burns \& H.L.A. Hart eds. 1970).

5. Id at 296.

6. Id.

7. Id. at $293-96$.

8. Bentham knew that he was creating a new term, but he thought that he was simply substituting one term for another without changing the scope of the field:

The word international, if must be acknowledged, is a new one; though, it is hoped, sufficiently analogous and intelligible. It is calculated to express, in a more significant way, the branch of law which goes commonly under the name of the law of nations: an appellation so uncharacteristic, that, were it not for the force of custom, it would seem rather to refer to internal jurisprudence. Id. at 296.

9. For a fuller treatment of Bentham's views on international law, see Janis, Jeremy Bentham and the Fashioning of "International Law," 78 AM. J. INT'L L. 405 (1984). For an eighteenth century case reflecting Blackstone's definition, see DeLongchamps, infra notes $17-20$ and accompanying text.

10. See J. Story, Commentaries on the Conflict of Laws, Forgign and DOMESTIC v (1st ed. 1834). 
international matters between individuals. John Austin argued that because public international law claimed to regulate matters between sovereign states which as sovereigns could not be regulated by any outside authority, international law was just a form of "positive morality" and not really law at all. ${ }^{11}$

Legal positivism had taken the eighteenth century law of nations, a law common to individuals and states, and transformed it into public and private international law. The former was deemed to apply to states, the latter to individuals. Positivists scorned both sides of the discipline. Public international law was "international" but not really "law." Private international law was "law" but not really "international." Even so insightful a modern positivist as $\mathrm{H}$. L. A. Hart assumed that the essence of international law was that it addressed states. ${ }^{12}$ Although Hart saw persuasive similarities between international and municipal law, he accepted uncritically Bentham's subject-based approach to the field. ${ }^{13}$

The positivist definition of international law has had an enormous impact on modern perceptions concerning the individual and international law. ${ }^{14}$ With few exceptions, the theory rejects the

11. See J. Austin, The Province of Jurisprudence Determined 140, 201 (ed. 1954).

12. See H.L.A. Hart, THE CoNCEPT OF LAW 208-31 (1961). 66.

13. On Hart's positivism and Professor Jones's article in this journal, see infra note

14. The following are but a few examples: "[In international law] the whole social body is united into one sovereign independent state, and only its relations with other such bodies are the subject of its investigations." J.T. ABDY, in KENT's COMMENTARY ON INTERNATIONAL LAW 7 (1866); "International law may be defined as the rules which determine the conduct of the general body of civilized states in their mutual dealings." T.J. LaWrenCE, The Principles of INTERnational LaW 1 (4th ed. 1910); "The exclusive business of International Law is to define the Rights and Duties of each State with reference to the rest." T.E. Holland, LECTURES ON INTERNATIONAL LAW 53 (1933); "International law consists of a body of rules governing the relations between states." 1 G. HACKWORTH, Digest OF INTERNATIONAL LAW 1 (1940); "The term international law may be fairly employed to designate the principles and rules of conduct declaratory thereof which States feel themselves bound to observe, and, therefore, do commonly observe in their relations with each other." C.C. HYDE, 1 INTERNATIONAL LAW CHIEFLY AS INTERPRETED AND APPLIED BY UNITED STATES I (2d ed. 1947); "The Law of Nations, or International Law, may be defined as the body of rules and principles of action which are binding upon civilized states in their relations with one another.” J.L. BRIERLY, THE LAW OF NATIONS 1 (6th ed. 1963). Brierly accepts Bentham's equation of the law of nations and international law.

International law has been defined as the body of "rules which are considered legally binding by states with each other," or "the principles which are in force between all independent nations." While some would see law as much more than-or even something different from-"rules" or "principles," there is common acceptance that international law is that law which governs relations between states, the basic units in the world political system during more than 300 years.

L. Henkin, R.C. Pugh, O. Schachter \& H. Smit, International Law Cases and Materials LVII (1980). See also P. Higgins, Studies In INTERNATIONAL LaW AND 
notion that individuals are proper subjects of public international law. ${ }^{15}$ Originally, the subject-based approach was merely Bentham's attempt to provide a rational way of explaining that law may have different subjects: individuals and states. ${ }^{16}$ While law can be categorized on the basis of its subjects, in practice the law of nations and international law have concerned more than the legal rights of states. As the next section demonstrates, positivism's subject-based definition was and remains oftentimes wrong in practice.

\section{THE SUBJECT-BASED DEFINITION OF INTERNATIONAL LAW AND SOME REALITIES OF INTERNATIONAL PRACTICE}

A prominent example of the failure of positivism to describe adequately the reality of the individual as a subject of international law comes from the time of Bentham himself. In Respublica v. De Longchamps, ${ }^{17}$ an American municipal court indicted the defendant for assaulting the Consul General of France to the new United States. It was held that the case "must be determined on the principles of the laws of nations."18 There was, following Blackstone, no doubt that an individual could be guilty of an infraction of the law of nations. ${ }^{19}$ De Longchamps, for his violation of the law of nations, was ordered to pay a fine of one hundred French crowns to the Commonwealth of Pennsylvania and to be imprisoned for "a little more" than two years. ${ }^{20}$

Even during the high tide of positivism, the United States Supreme Court had no difficulty seeing individuals as subjects of international law. In The Paquete Habana, ${ }^{21}$ the United States Navy had seized two Cuban fishing smacks in the opening days of the

Relations 16 (1928); I. Brownlie, Principles of Public International LaW 69 (3d ed. 1979); D.W. GrIEG, INTERNATIONAL LaW 1, 116 (2d ed. 1976); M. AKEHURST, A Modern Introduction to INTERnational LaW 1 (4th ed. 1982); A. FaVre, PrinciPLES DU DROIT DES GENS 11, 17 (1974); AKADEMIE DER WISSENSCHAFTEN DER UDSSR RECHTSINSTITUT VOLKERRECHT 1 (1960).

15. A greater willingness to see international law include individuals as its subjects is found in H. KelseN, PRINCIPLes OF INTERNATIONAL LAW 180-290 (1966). Kelsen sees all law as applying to individuals and the international legal responsibility of a state as "nothing but the collective responsibility of the individuals belonging to the community represented as a juristic person." Id. at 182.

16. See supra notes 4-9 and accompanying text.

17. 1 U.S. (1 Dall.) 111 (1784).

18. Id. at 114 .

19. The Court stated that " $[t]$ he person of a public minister is sacred and inviolable. Whoever offers any violence to him, not only affronts the Sovereign he represents, but also hurts the common safety and well-being of nations; he is guilty of a crime against the whole world." Id. at 116.

20. Id. at 118.

21. 175 U.S. 677 (1900). 
Spanish-American War. A lower federal court condemned the boats as prizes of war. The masters for themselves, their crews, and their owners, argued before the Supreme Court that peaceful fishing craft were exempt from seizure under the rules of international law. In perhaps the most famous statement ever made about international law by a United States court, the Supreme Court held that "[i]nternational law is part of our law, and must be ascertained and administered by the courts of justice of appropriate jurisdiction, as often as questions of right depending upon it are duly presented for their determination." 22 The Court held that:

By an ancient usage among civilized nations, beginning centuries ago, and gradually ripening into a rule of international law, coast fishing vessels, pursuing their vocation of catching and bringing in fresh fish, have been recognized as exempt, with their cargoes and crews, from capture as prize of war. ${ }^{23}$

Individuals had a right to rely on this rule as against the United States. The Court ordered the government to pay over the proceeds of the sale of the vessels and their cargoes to the individual claimants. 24

However inadequately subject-based theory accounted for individual rights and obligations in international law in the eighteenth and nineteenth centuries, positivism has done an even poorer job in explaining the practices of the twentieth century. The trials of Nazi war criminals after the Second World War highlighted the limitations of positivism. Faced with the excesses of a seemingly "civilized" state, those formulating and applying international law discarded any pretense that international rules applied only to state behavior.

The Charter of the International Military Tribunal at Nuremberg explicitly made individuals subject to international rules relating to crimes against peace, war crimes, and crimes against humanity. ${ }^{25}$ At Nuremberg and in other war trials, thousands of

22. Id. at 700 .

23. Id. at 686 .

24. Id. at 714 .

25. The Charter provided:

\section{Article 6 .}

The following acts, or any of them, are crimes coming within the jurisdiction of the Tribunal for which there shall be individual responsibility:

(a) CRIMES AGAINST PEACE: namely, planning, preparation, initiation or waging of a war of aggression, or a war in violation of international treaties, agreements or assurances, or participation in a common plan or conspiracy for the accomplishment of any of the foregoing;

(b) WAR CRIMES: namely, violations of the laws or customs of war. Such violations shall include, but not be limited to, murder, ill-treatment or deportation to slave labor or for any other purpose of civilian population of or in occupied territory, murder or ill-treatment of prisoners of war or persons on the seas, 
individuals were tried and convicted; hundreds were executed. ${ }^{26}$ Nuremberg re-established plainly and forcefully that the rules of international law should and do apply to individuals. The Nuremberg Tribunal held that "[c]rimes against international law are committed by men, not by abstract entities, and only by punishing individuals who commit such crimes can the provisions of international law be enforced."27

The Nuremberg trials were not isolated events. They had a profound influence on other elements of modern international law. For example, they had an important impact on the formulation and implementation of the 1950 European Convention for the Protection of Human Rights and Fundamental Freedoms. ${ }^{28}$ The European Convention provides that party states shall secure to everyone within their jurisdiction certain rights and freedoms. These include the right to life, freedom from torture or inhumane or degrading punishment, freedom from slavery or servitude, the right to liberty and security of person, the right to a fair trial, freedom from ex post facto laws, the right to private life and correspondence, freedom of thought and religion, freedom of expression, the rights to assembly and trade unions, and the right to marry and found a family. ${ }^{29}$

The European Convention has been accepted throughout West-

killing of hostages, plunder of public or private property, wanton destruction of cities, towns or villages, or devastation not justified by military necessity;

(c) CRIMES AGAINST HUMANITY: namely, murder, extermination, enslavement, deportation, and other inhumane acts committed against any civilian population, before or during the war, or persecutions on political, racial or religious grounds in execution of or in connection with any crime within the jurisdiction of the Tribunal, whether or not in violation of the domestic law of the country where perpetrated.

Leaders, organizers, instigators and accomplices participating in the formulation or execution of a common plan or conspiracy to commit any of the foregoing crimes are responsible for all acts performed by any persons in execution of such plan.

Article 7.

The official position of defendants, whether as Heads of State or responsible officials in Government Departments, shall not be considered as freeing them from responsibility or mitigating punishment.

Article 8.

The fact that the Defendant acted pursuant to order of his Government or of a superior shall not free him from responsibility, but may be considered mitigation of punishment if the Tribunal determines that justice so requires.

Agreement for the Prosecution and Punishment of The Major War Criminals OF THE EUROPEAN AXIS, signed August 8, 1945, 59 Stat. 1544, 1547-48, E.A.S. No. 472 (emphasis added).

26. See E. Davidson, The Trial of the Germans 1-38 (1972).

27. The Nuremberg Trial, 6 F.R.D. 69, 110 (Int'1 Military Tribunal 1946).

28. Convention for the Protection of Human Rights and Fundamental Freedoms. November 4, 1950, 213 U.N.T.S. 221 [hereinafter cited as European Human Rights Convention].

29. Id. at arts. 1-12. 
ern Europe. ${ }^{30}$ The Convention not only formulates substantive international rights, but also creates a set of institutions to enforce these rights: a European Commission of Human Rights and a European Court of Human Rights, both sitting in Strasbourg. ${ }^{31}$ The structure of these institutions and individuals' access to them is important and worth noting in some detail.

The Commission consists of twenty members, one from each contracting state. ${ }^{32}$ Any contracting state may refer to the Commission any alleged breach of the provisions of the European Convention by another contracting party. ${ }^{33}$ Furthermore, persons, nongovernmental organizations, and groups of individuals may petition the Commission with claims of violations of the Convention. The right of individual petition is limited to complaints against states that have recognized the competence of the Commission to receive such petitions, ${ }^{34}$ but sixteen of the twenty contracting parties have declared their recognition of such competence. ${ }^{35}$ The Commission decides the admissibility of petitions by referring to the rules of the Convention. ${ }^{36}$ If the petition is admissible, the Commission investigates the complaint and attempts to secure a friendly settlement between the parties. ${ }^{37}$ If the parties can not reach an amicable settlement, the Commission submits a Report to the Council of Europe. ${ }^{38}$

After the Commission has reported, a case may be referred to the European Court of Human Rights. ${ }^{39}$ There are twenty-one judges on the Strasbourg court, one for each member of the Council of Europe. ${ }^{40}$ Eighteen of the twenty Convention members recognize the compulsory jurisdiction of the court.41 Either the Commission or a member state may refer a case to the court. ${ }^{42}$ Although an individual complainant does not have a right to refer a case to the court, the

30. Twenty countries are now parties: United Kingdom, France, West Germany, Italy, the Netherlands, Belgium, Luxembourg, Ireland, Denmark, Greece, Norway, Sweden, Iceland, Austria, Switzerland, Spain, Portugal, Cyprus, Malta and Turkey. EuroPEAN COMMISSION OF HUMAN RIghts, STOCK-TAKING ON THE EUROPEAN Convention on Human Rights 8 (1982) [hereinafter cited as Stock-Taking on THE EUROPEAN CONVENTION].

31. European Human Rights Convention, supra note 28, art. 19.

32. Id. at art. 20 .

33. Id. at art. 24.

34. Id. at art. 25.

35. Stock-Taking on the European Convention, supra note 30, at 8. The nonconsenting states are Greece, Cyprus, Malta, and Turkey. Id.

36. European Human Rights Convention, supra note 28, at art. 27.

37. Id. at art. 28.

38. Id. at art. 31.

39. Id. at arts. $46-49$.

40. Id. at art. 38 .

41. Stock-Taking on the European Convention, supra note 30 , at 8 . The two non-consenting states are Malta and Turkey. Id.

42. European Human Rights Convention, supra note 28, at art. 44. 
Commission can and frequently will refer the case so as to secure a legally binding decision on the individual's behalf. Thus, the Court can rule against a state even though the state has not referred the case to the court. 43

The European human rights system maintains an active schedule. In 1981, the Commission provisionally opened 2672 files, officially registered 404 applications, rendered 430 decisions, and launched 21 investigations. 44 The Strasbourg Court handed down five judgments. The Court's workload has been increasing: there were only ten decisions between 1960 and 1969, but the Court made twenty-four judgments in the 1970's and it already has decided sixteen cases in the first two and a half years of this decade.

Individual applications figure prominently in the work of the European Commission and Court of Human Rights. As of September 30, 1981, the European Commission had received (since 1953) only thirteen petitions lodged by states; it had, however, received about 9560 applications from individuals. ${ }^{45}$ This means that the European human rights system was receiving even fewer inter-state, international cases than the infrequently consulted International Court of Justice. ${ }^{46}$ It is the total of individual applications which makes the European human rights system a vital aspect of international law. In contrast, the International Court of Justice, in a positivist, subject-based fashion, does not accept individuals as claimants. ${ }^{47}$

Moreover, the European human rights system operates effectively. It is an international legal system that is respected in practice. The Court, for example, has found England in violation of a prisoner's right to correspond with his lawyers, ${ }^{48}$ the Netherlands in violation of a soldier's right to a fair disciplinary hearing, 49 and Italy in violation of a detainee's right to be detained only after conviction or for the purpose of a hearing. ${ }^{50}$ In these and other cases, the govern-

43. Id. at art. 48. See the judgments of the European Court of Human Rights in The Sunday Times Case, 1979 Y.B. Eur. Conv. ON Human Rights 403 and the Airey Case, 1979 Y.B. Eur. Conv. ON Human Rights 420.

44. StOck-TAKING ON THE EuROPEAN Convention, supra note 30, at 224.

45. Id. at 12 .

46. On average, the International Court of Justice and its predecessor, the Permanent Court of International Justice, have rendered about two judgments or advisory opinions each year. Between 1922 and 1940 the PCIJ recorded 31 judgments and 27 advisory opinions. The ICJ rendered 42 judgments and 18 advisory opinions between 1946 and 1982. I.C.J.Y.B. 153-64 (1982).

47. I.C.J. Stat. Art. 34(1) provides: "Only States may be parties in cases before the Court." International Court of Justice, Series D, Acts and Documents Concerning the Organization of the Court (May 1947).

48. Golder Case, 1975 Y.B. Eur. Conv. on Human Rights 290.

49. Engel Case, 1976 Y.B. Eur. Conv. On Human Rights 490.

50. Guzzardi Case, 1980 Y.B. Eur. Conv. ON HuMAN RIGHTS 484. 
ment concerned has respected the judgment of the Court. The contrast to the International Court of Justice, where countries often have disregarded the court's proceedings, is plain. ${ }^{51}$

Furthermore, the European human rights system has served as a model for other regions. The drafters of the American Convention on Human Rights followed the European example. ${ }^{52}$ Like the European Convention, the American Convention established certain fundamental human rights and a commission and court to protect these rights. ${ }^{53}$ Unlike the European human rights system, the new American system has no impressive collection of enforcement actions. But an advisory opinion of the Inter-American Court of Human Rights clarified the fundamental role of the individual in the international law system existing under the American Convention. ${ }^{54}$

The European Economic Community (E.E.C.) provides another important example of rules and process applicable to individuals under modern international law. The E.E.C. is composed of ten nations adhering to the 1957 Treaty of Rome.5s The Rome Treaty primarily concerns economic matters. It provides for a customs union, a common agricultural market, free movement of persons, services and capital, and common policies for such matters as trans-

51. In four recent contentious ICJ cases, defendant states have simply refused to appear: Iceland, in Fisheries Jurisdiction (W. Ger. v. Ice.), 1974 I.C.J. 175 (Judgment of July 25); France, in Nuclear Tests (Austl. v. Fr.), 1974 I.C.J. 253 (Judgment of Dec. 20); Turkey, in Aegean Sea Contintental Shelf (Greece v. Turk.), 1978 I.C.J. 3 (Judgment of Dec. 19); and Iran, in United States Diplomatic and Consular Staff in Tehran (U.S. v. Iran), 1980 I.C.J. 3 (Judgement of May 24). Despite such disregard, I.C.J. proceedings still may serve a useful purpose. See Janis, The Role of the International Court in the Hostages Crisis, 13 ConN. L. Rev. 263 (1981).

52. American Convention on Human Rights, entered into force July 18, 1978, OAS Treaty Series No. 36, at 1-21 OEA/Ser. A/16, [English] [hereinafter cited as American Convention on Human Rights]. For a history of the ratification of the American Convention and a reprint of its text, see Human Rights: The INTER-AMERICAN SYSTEM, Part I, Ch. II, i (T. Buergenthal \& R. Norris eds. 1982).

53. American Convention on Human Rights, supra note 52 at arts. 3-25, 33-73.

54. [M]odern human rights treaties in general, and the American Convention in particular, are not multilateral treaties of the traditional type concluded to accomplish the reciprocal exchange of rights for the mutual benefit of the contracting States. Their object and purpose is the protection of the basic rights of individual human beings, irrespective of their nationality, both against the State of their nationality and all other contracting States. In concluding these human rights treaties, the States can be deemed to submit themselves to a legal order within which they, for the common good, assume various obligations, not in relation to other States, but towards all individuals within their jurisdiction.

The Effect of Reservations on the Entry into Force of the American Convention, InterAmerican Court of Human Rights, Advisory Opinion No. OC-2/82 (Sept. 24, 1982), reprinted in 22 I.L.M. 37, 47 (1983).

55. Treaty Establishing the European Economic Community, March 25, 1957, 298 U.N.T.S. 3. [hereinafter cited as E.E.C. Treaty]. The ten countries are Belgium, Denmark, France, Great Britain, Greece, Ireland, Italy, Luxembourg, the Netherlands, and West Germany. 
portation and competition. 56

An important component of the regional international legal system of the E.E.C. is the European Court of Justice in Luxembourg. ${ }^{57}$ The Luxembourg Court hears cases brought not only by states and by the Community's international institutions, the Council and the Commission, but also by individuals. ${ }^{58}$

The European Court of Justice also may advise municipal courts on cases that involve individual claims against states or other individuals. ${ }^{59}$ In addition, the court has jurisdiction in cases involving damages caused by the institutions of the Community or its servants and in cases brought by employees of the E.E.C. against Community institutions. ${ }^{60}$

The European Court of Justice explicitly recognized the applicability of E.E.C. law to individuals in the famous Van Gend en Loos

56. Id. at arts. $9,38,48,59,67,74,85,86$.

57. The court is composed of eleven judges, one from each member country, and an extra judge appointed on a rotating basis from one of the four largest E.E.C. member states. D. LASOK \& J. BRIDGE, LAW AND INSTITUTIONS OF THE EUROPEAN COMMUNITIES 221 (3d ed. 1982).

58. For example, Article $\mathbf{1 7 3}$ of the E.E.C. Treaty provides:

The Court of Justice shall review the legality of acts of the council and the Commission other than recommendations or opinions. It shall for this purpose have jurisdiction in actions brought by a Member State, the Council or the Commission on grounds of lack of competence, infringement of an essential procedural requirement, infringement of this Treaty or of any rule of law relating to its application, or misuse of powers.

Any natural or legal person may, under the same conditions, institute proceedings against a decision addressed to that person or against a decision which, although in the form of a regulation or a decision addressed to another person, is of direct and individual concern to the former.

E.E.C. Treaty, supra note 55 at art. 173 (emphasis added).

59. Article 177 of the E.E.C. Treaty states:

The Court of Justice shall have jurisdiction to give preliminary rulings concerning:

(a) the interpretation of this treaty;

(b) the validity and interpretation of acts of the institutions or the Community;

(c) the interpretation of the statutes of bodies established by an act of the Council, where those statutes so provide.

Where such a question is raised before any court or tribunal of a Member State, that court or tribunal may, if it considers that a decision on the question is necessary to enable it to give judgment, request the Court of Justice to give a ruling thereon.

Where any such question is raised in a case pending before a court or tribunal of a Member State, against whose decision there is no judicial remedy under national law, that court or tribunal shall bring the matter before the Court of Justice.

Id. at art. 177. The purpose of Article 177 is "to ensure a uniform interpretation and application of Community law," Bebr, Preliminary Rulings of the Court of Justice: Their Authority and Temporal Effect, 18 CoMmoN MKT. L. REv. 475 (1981). For a further discussion of Article 177, see Van Gerven, The Legal Protection of Private Parties in the Law of the European Economic Community, in EUROPEAN LAW AND THE INDIVIDUAL 1 (Jacobs ed. 1976).

60. E.E.C. Treaty, supra note 55, at arts. 178, 179. 
case. ${ }^{61}$ The Court has also held that the conflicting rules of municipal legal systems must give way to E.E.C. law. ${ }^{62}$

As with the European Court of Human Rights, ${ }^{63}$ the vast bulk of cases before the European Court of Justice has been brought by individuals, not by states. As of December 31, 1982, 272 of the 322 cases brought against the E.E.C. under Article 173 have been brought by individuals. ${ }^{64}$ In addition, there have been 1030 Article 177 cases, most involving individual rights and obligations, and 1983 actions brought by E.E.C. employees. ${ }^{65}$

Again, the contrast with traditional positivist doctrine is striking. The European Court of Justice is a busy international court. In terms of actual caseload, it is far more important than the International Court of Justice. It hears, on a regular basis, cases brought by and involving individual litigants and determines the rights and obligations of individuals based on the international legal rules embodied in the Treaty of Rome and formulated by the E.E.C.'s international institutions. In the face of this practice, it is unrealistic to theorize that individuals are not subjects of international law. Clearly, in E.E.C. law individual rights and obligations are very much at issue. In E.E.C. practice, individual litigants often are important subjects of the international proceedings. ${ }^{66}$

\section{The court held:}

[T] he Community constitutes a new legal order in international law, for whose benefit the States have limited their sovereign rights, albeit within limited fields, and the subjects of which comprise not only member States but also their nationals. Community law, therefore, apart from legislation by the member States, not only imposes obligations on individuals but also confers on them legal rights.

Case 26/62 Ven Gend en Loos v. Nederlandse Administratie der Belastingen [1963] E.C.R. 1, 23, 2 Comm. Mkt. L.R. 105, 129 (1963) (emphasis added). There is sometimes said to be a distinction in E.E.C. law between "direct applicability," i.e., the incorporation of E.E.C. law into municipal law, and "direct effect," i.e., the capability to enforce judicially an E.E.C. rule. Both concepts concern individual rights and obligations and, whatever the validity of the distinction, are covered by the American notion of "selfexecuting" provisions of international agreements. See Winter, Direct Applicability and Direct Effect: Two Distinct and Different Concepts in Community Law, 9 CoMMON MKT. L. REv. 425 (1972).

62. "[E]very national court must, in a case within its jurisdiction, apply Community law in its entirety and protect rights which the latter confers on individuals and must accordingly set aside any provision of national law which may conflict with it, whether prior or subsequent to the Community rule." Case 106/77 Amministrazione delle Finanze dello Stato v. Simmenthal, [1978] E.C.R. 629, 644, 23 Comm. Mkt. L.R. 263, 283 (1978).

63. See supra text accompanying notes $45-47$.

64. Commission on the European Communtties, Sixteenth General Report ON THE ACTIVITIES OF THE EUROPEAN COMMUNTIES 1982 338-39 (1983).

65. Id.

66. For an illuminating discussion of individuals as subjects of E.E.C. law, see this journal's article by Professor Jones, 17 CoRNELI INT'L L.J. 1 (1984), especially its Section Three. Although there is much that Professor Jones and I seem to agree about, the reader will note an important discord. Professor Jones uses the effect of E.E.C. law on 
One final and compelling example from modern practice is the recent decision of the United States Court of Appeals for the Second Circuit in Filartiga v. Peña-Irala ${ }^{67}$ In Filartiga, where both sides to the dispute were individuals, the court found international law dispositive on a threshold jurisdictional question. ${ }^{68}$

The plaintiffs, Paraguayan citizens, were the father and sister of another Paraguayan, who, they contended, had been tortured and killed in Paraguay by defendant Peña-Irala, also a Paraguayan. ${ }^{69}$ The plaintiffs based their claim on a provision from the Judiciary Act of 1789 providing that "[t]he federal district courts shall have original jurisdiction of any civil action by an alien for a tort only, committed in violation of the law of nations."70 This statutory provision is an example of the eighteenth century view of the relationship between individuals and the law of nations. In 1789, the year Bentham published his definition of international law, the United States Congress authorized suits by individuals under the law of nations. It is a fascinating and circuitous occurrence when a modern court turns to an eighteenth century law of nations theory embodied in a statutory provision that has outlasted the restrictive doctrines of positivism.

The Filartiga court surveyed the international rules relating to torture looking to customary practice, treaty provisions, municipal law, opinions of experts, and international resolutions. ${ }^{71}$ The court concluded that "an act of torture committed by a state official against one held in detention violates established norms of the international law of human rights, and hence the law of nations."72 Moreover, the court overruled dictum from an earlier decision and held that "international law confers fundamental rights upon all people vis-a-vis their own governments."73 In deciding the threshold question of federal court jurisdiction to hear this claim of an alien against another alien for alleged violations of international law, the court concluded with language that echoes the concerns of the

the individual to demonstrate how different E.E.C. law is from international law; I use it as one example to demonstrate that the positivists are wrong about the proper subjects of international law. Thus, Professor Jones distinguishes E.E.C. and international law; I use the one to show the nature of the other.

67. 630 F.2d 876 (2d Cir. 1980).

68. Id. at 880 .

69. Id. at 878 .

70. Alien Tort Statute, (codified at 28 U.S.C. $\S 1350$ (1976)).

71. See Filartiga, 630 F.2d at $880-84$.

72. Id. at 880 .

73. The court refuted the following dictum from an earlier decision: "Violations of international law do not occur when the aggrieved parties are nationals of the acting state." Id. at 884 (quoting Dreyfus v. Von Finck, 534 F.2d 24, 31 (2d Cir. 1976), cert. denied, 429 U.S. 835 (1976)). 
Nuremberg Charter and the 1950 European Human Rights convention. ${ }^{74}$

All of these examples-De Longchamps, Paquete Habana, the Nuremberg trials, the European and American human rights systems, the European Economic Community, and Filartiga-demonstrate that a large and important part of international law practice establishes individual rights and obligations and provides international and municipal procedures for enforcing these rights and obligations. ${ }^{75}$ The reality of practice contradicts the positivist insistence that international law applies only to relations among states. Insofar as the purpose of theory is to describe reality, the positivist, subjectbased theory is inadequate.

Furthermore, restricting international law to states fails a second test by which positivism may be measured-its prescriptive worth. Surely, it is counter to the proper values of international law to prescribe that individuals may not be the subjects of international law. It was, at the time of the Nuremberg trials, politically and morally unacceptable to say that individuals within the German State between 1933 and 1945 were subjects only of German law to whom international rights and obligations could not pertain. In light of the atrocities of Nazi Germany, it would have been reprehensible to leave victims without legal rights and perpetrators without legal obligations. The lesson of Nuremberg is that there are individual international rights and obligations that transcend state boundaries.

74. In the twentieth century the international community has come to recognize the common danger posed by the flagrant disregard of basic human rights and particularly the right to be free of torture. Spurred first by the Great War, and then the Second, the civilized nations have banded together to prescribe acceptable norms of international behavior. From the ashes of the Second World War arose the United Nations Organization, amid hopes that an era of peace and cooperation had at last begun. Though many of these aspirations have remained elusive goals, that circumstance cannot diminish the true progress that has been made. In the modern age, humanitarian and practical considerations have combined to lead the nations of the world to recognize that respect for fundamental human rights is in their individual and collective interest. Among the rights universally proclaimed by all nations, as we have noted, is the right to be free of physical torture. Indeed, for purposes of civil liability, the torturer has becomelike the pirate and slave trader before him-hostis humani generis, an enemy of all mankind. Our holding today, giving effect to a jurisdictional provision enacted by our First Congress, is a small but important step in the fulfillment of the ageless dream to free all people from brutal violence.

Filartiga, 630 F.2d at 890.

75. For further examples of individual obligations at international law in municipal courts, see Komarow, Individual Responsibility Under International Law: The Nuremberg Principles in Domestic Legal Systems, 29 INT'L \& CoMP. L.Q. 21 (1980). For an outstanding examination of the rights of individuals at international law, see Sohn, The New International Law: Protection of the Rights of Individuals Rather than States, 32 AM. U.L. REV. 1 (1982). 
Similar considerations pertain to international communities such as the Council of Europe and the European Economic Community. These groups have recognized the need to extend certain basic human and economic rights and obligations directly to individuals even though these rights and obligations emanate not from municipal law but from international law. Given the difficulty of addressing some issues, such as human rights and economic development, through municipal legal systems alone, such an extension of international law rules to individuals makes sense. It is impressive that, with the European Human Rights system and the legal system of the E.E.C., the Europeans have begun to open international legal processes to individuals.

It is wrong, both in terms of describing reality and in terms of preferential expression, for the theory of international law to hold that individuals are outside the ambit of international law rules. Individuals are and should be within this realm. The positivist notion that individuals are not fit subjects for international law springs not from a description of reality, but from a jurisprudential philosophy most concerned with a subject-based categorization of types of law. In so categorizing international law, the positivist theorists simply discarded the more inclusive notions of the law of nations. Whatever the impact of positivist theory, it never absolutely represented the practice of any time. Today, reality and preference have so revealed the weakness and obsolescence of subject-based theory that the sooner we rid ourselves of it the better.

\section{A SPECULATION: A SOURCE-BASED CONCEPT OF INTERNATIONAL LAW}

If we reject the positivist's subject-based definition of international law, then what should be our new concept of the nature of international law? What are the objections to reverting to Blackstone's understanding that the discipline should be characterized by its reliance on universal and multinational sources?"6

One might say that, so characterized, international law is not properly "inter-national," but this is a rather superficial problem. Bentham supposed international law to be the equivalent of the law of nations, but it was not.77 So, the fault, if any, in matching the term and the content of international law must rest with its creator. We could easily use the old term, law of nations, and eliminate the linguistic quibble. But the term "international law" is too much in use to abandon it now. I suggest that we continue using the word

76. See supra text accompanying notes 1-3.

77. See supra text accompanying note 9. 
international but understand "nation" to mean not only the national state but also the individuals who are the nationals of the state. This meaning is both true to the word "nation" and finally makes sense of Bentham's equivalence between the law of nations and international law.

A second objection to reverting to Blackstone's emphasis on sources as a way of understanding international law might be that such a reversion mixes public and private international law. Even though positivists might reject such a mixing, it may, in fact, be a blessing. Some positivists have been dissatisfied with calling some rules "international" because they did not properly concern state behaviour. Bentham relegated "private" matters to municipal law, 78 while Story defined his discipline of conflict of laws in a similar fashion. ${ }^{79}$

From the time Bentham excluded rules relating to individuals from his new realm of international law, all such rules concerning individuals' contacts with foreign states and foreign parties remained more or less unclassified until Story collected some of them in his new discipline of conflict of laws or, as it is sometimes called, private international law. Others of the cast-off rules, especially those pertaining to international commercial law, really have never fit into existing classifications. ${ }^{80}$

If the positivists' exclusion of individuals from the ambit of international law was wrong, then perhaps it makes no sense to divide the discipline into "public" and "private" sides. In fact, there exists a body of case law that makes no clear distinction between private and public international law. For example, Hilton v. Guyot, ${ }^{81}$ a case decided in 1895 during a period of great positivist influence, would seem to be representative of what the positivists might con-

78. Bentham stated:

Now as to any transactions which may take place between individuals who are subjects of different states, these are regulated by the internal laws, and decided upon by the internal tribunals, of the one or the other of these states: the case is the same where the sovereign of the one has an immediate transaction with a private member of the other, the sovereign reducing himself, pro re nãta, to the condition of a private person, as often as he submits his cause to either tribunal whether by claiming a benefit; or defending himself against a burthen.

J. BENTHAM, supra note 4, at 296.

79. Story's discipline of conflict of laws concerned 'the operation of the laws of one nation upon the rights and remedies of parties in the domestic tribunals, especially when they were in any measure dependent upon, or connected with foreign transactions." J. STORY, supra note 10 , at 2.

80. Authors trying to organize and discuss the rules pertaining to international commerce have experienced difficulties because of the theoretical divisions of international and municipal law. See Y. LOUSSOUARN \& J.D. BREDIN, DROIT DU COMMERCE INTERNATIONAL 1-13 (1969).

81. 159 U.S. 113 (1895). 
sider private international law. The liquidator and members of a French commercial firm came to the Southern District of New York seeking to enforce a judgment of a French court for debts owed in France by a U.S. firm. In determining whether the French judgment was entitled to recognition, the Supreme Court broadly defined the scope of international law, foreshadowing its holding in The Paquete Habana ${ }^{82}$ The Court's search for the right rule, a detailed examination of the notion of comity, was a classic example, not of the search for a rule of municipal law, but of a search for a rule of the law of nations. The Court turned not only to American practice but to the practice of more than twenty-five other countries as well. ${ }^{83}$ The Court concluded that "[i]t appears, therefore, that there is hardly a civilized nation on either continent, which, by its general law, allows conclusive effect to an executory foreign judgment for the recovery of money .... [T] [Te rule of reciprocity has worked itself firmly into the structure of international jurisprudence." 84

To characterize Hilton as private, not public, international law, is to insist upon an unnatural interpretation. Clearly, the Court felt its job was not merely to find the municipal rule of the U.S. legal system. Rather, the task was to examine "international jurisprudence" in an attempt to find in international sources some common rule that was useful and applicable not only in the United States but anywhere in the civilized world. The search was similar to that made by the Court in Paquete Habana in a matter ostensibly concerning what the positivists would define as public international law. What really characterizes Hilton and Paquete Habana is not that the subjects involved were private and public, but that the sources of the rules in both cases were multinational. The role of international law in Hilton is much closer to Blackstone's eighteenth century notions of the utility of the law of nations in commercial disputes than it is to the ideas of either Bentham or Story. Blackstone thought that the law of nations, rather than municipal law, should govern matters of

82. The Court stated:

International law, in its widest and most comprehensive sense-including not only questions of right between nations, governed by what. has been appropriately called the law of nations; but also questions arising under what is usually called private international law, or the conflict of laws, and concerning the rights of persons within the territory and dominion of one nation, by reason of acts, private or public, done within the dominions of another nation-is part of our law, and must be ascertained and administered by the courts of justice, as often as such questions are presented in litigation between man and man, duly submitted to their determination.

Id. at 163 .

83. See id. at $162-227$.

84. Id. at 227. 
international trade and commerce. ${ }^{85}$ Thus, Blackstone's answer to the problem of conflict of laws was to find the rule agreed upon by most or all the states. This is exactly the course followed by the Court in Hilton.

Modern practice recognizes that conflict of laws is not just a species of international law. Rather, conflict of laws is, as Story saw it, a matter of municipal, not international law. My argument is not that the theory separating public from private international law is out of step with practice; clearly the theory is reflective of practice. Rather, I suggest that theory should begin encouraging practice, at least in some cases, to move closer to reintegrating public and private international law.

My argument is partly developmental. Private international law grew out of those rules that remained after the positivists narrowed the focus of the law of nations. For the positivists, international law or public international law properly concerned only relations between states. This classification did not and does not reflect the realities of international practice.

If individuals are within the scope of public international law as well as that of private international law, what need is there to assume that the rules of private international law are solely municipal? In Hilton, the Court engaged in a search for a rule that was internationally-founded, that is, a rule that emanated from multinational sources. I suggest that such a multinational search is right and proper. Given an international problem and a preference for accord and harmony among the states, it is sensible to attempt to find rules that are acceptable outside the narrow boundaries of a municipality. This is true for several reasons. First, it will be fair to foreigners and pleasing to foreign states in the specific case. Second, it will encourage foreign states to reciprocate and treat aliens fairly and in accordance with general rules. Finally, it will benefit international transactions generally to have foreseeable rules applicable commonly in many fora. Such an approach returns to Blackstone's belief that a uniform international law of commerce was the best way of assuring similar and fair treatment to English merchants.

Perhaps the most telling argument in favor of a source-based definition of international law is that it is a realistic reflection of

85. Blackstone stated:

Whereas no municipal laws can be sufficient to order and determine the very extensive and complicated affairs of [foreign traffic and merchandize, neither can they have a proper authority for this purpose. For as these are transactions carried on between the subjects of independent states, the municipal laws of one will not be regarded by the other.

1 W. BlaCKSTONE, supra note 1, at 263-64. 
what courts actually do when they search for public and often-times private rules of international law. All of the U.S. cases discussed above-De Longchamps, The Paquete Habana, Filartiga, Hiltonutilize a comparative approach and look at the practice of other states. While there are other instances of this approach, Story's judgment in United States v. Smith ${ }^{86}$ is one of the more compelling examples of this practice. The Court considered whether Congress needed to define more precisely its statutory definition of the crime of piracy. Story held that no detailed congressional definition of piracy was needed because piracy was defined precisely by the law of nations. ${ }^{87}$ To demonstrate this recognition, Story wrote a footnote that catalogued numerous foreign authorities' treatment of piracy. The footnote, a potent display of legal scholarship and a foreboding of footnotes in modern-day law review articles, takes up most of 18 pages of printed text, above which the unfortunate Justice Livingstone has on each page but two lines of dissent. ${ }^{88}$ A more recent example of such a reliance on multinational sources is Victory Transport, Inc. v. Comisaria General ${ }^{89}$ The Second Circuit characterized the Spanish governments' chartering of a vessel carrying grain as an act jure gestionis rather than one jure imperii by showing similar treatment in Egypt, France, Italy and Belgium. ${ }^{90}$ If the courts so commonly turn to multinational sources to find rules of international law, why not recognize that it is the nature of the rule search, not the nature of the subjects, that defines the discipline?

\section{CONCLUSION}

It is high time to realize that positivism's subject-based approach to international law is neither realistically descriptive nor beneficially prescriptive. While it is true that international law frequently concerns states inter se, oftentimes international law directly involves individuals. It will be better to focus our attention on the universal and multi-state sources of both public and private international law. Such a focus better distinguishes international from municipal law. It usefully encourages courts and other law finders and appliers to look outside national sources for rules of decision in international cases.

86. 18 U.S. (5 Wheat.) 153 (1820).

87. Id. at $157-63$.

88. See id. at $163-80$.

89. 336 F.2d 354 (2d Cir. 1964).

90. Id. at 360-61. See also The Bremen v. Zapata Off-Shore Co., 407 U.S. 1 (1972), where the Court refers favorably to the approach of the English courts towards the enforcement of foreign forum selection clauses. 